\title{
A VÍZSUGARAS ESZTERGÁLÁS SAJÁTOSSÁGAI
}

\author{
Kun-Bodnár Krisztina
}

egyetemi tanársegéd, Miskolci Egyetem, Gyártástudományi Intézet

3515 Miskolc, Miskolc-Egyetemváros, e-mail: krisztina.bodnar@uni-miskolc.hu

\begin{abstract}
Absztrakt
A cikk az abraziv vizsugaras vágógépen végzett esztergálási kísérleteket és az ahhoz szükséges forgató berendezés, technológiai adatok, eljárások megválasztásának szempontjait mutatja be.
\end{abstract}

Kulcsszavak: vízsugaras esztergálás, forgató berendezés, $\mathrm{AlMg} 0,7 \mathrm{Si}$ ötvözet

\section{Abstract}

This paper demonstrates a solution for machining cylindrical surfaces with abrasive waterjet. We have developed an equipment for this. The design aspects, the device, the experimental conditions, and the technological parameters are presented in the paper.

Keywords: waterjet turning, rotating equipment, $\mathrm{AlMgO}, 7 \mathrm{Si}$

\section{Bevezetés}

Az alábbi cikk összefoglalója az EFOP-3.6.1-16-2016-00011 jelü „Fiatalodó és Megújuló Egyetem Innovatív Tudásváros - a Miskolci Egyetem intelligens szakosodást szolgáló intézményi fejlesztése" projekt keretében végzett kutató munkámnak, melyben feladatom volt a vízsugaras megmunkálások tanulmányozása, kísérleti berendezés tervezése és adaptálása vízsugaras megmunkálógéphez, kísérletek végzése, adatfeldolgozás, értékelés, valamint az eredmények közlése. A vízsugaras megmunkálások közül az abrazív vízsugárral történő esztergálással foglalkoztam, mely lehetővé teszi forgásszimmetrikus alkatrészek, mint hengeres vagy kúpos felületek előállítását olyan anyagokból, melyek hagyományos esztergálással nem munkálhatóak meg. Vízsugaras esztergálásnál a munkadarab $\mathrm{v}_{\mathrm{fc}}$ sebességgel forog, miközben a sugár egy meghatározott beállított fogásmélységen $\left(\mathrm{a}_{\mathrm{p}}\right)$ tengelyirányban $\mathrm{v}_{\mathrm{fa}}$ sebességgel mozog (1. ábra).

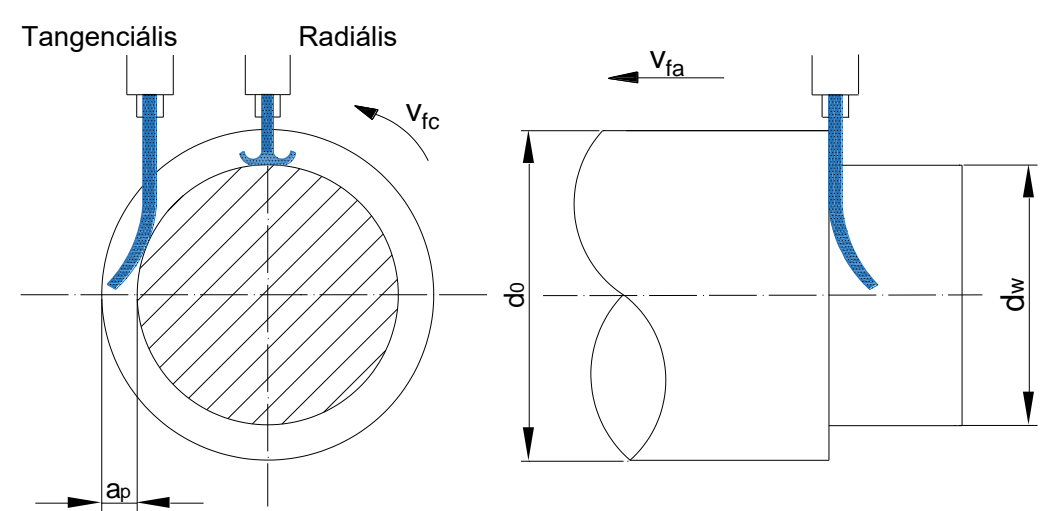

1. ábra: Abrazív vizsugaras esztergálás 
Az anyagleválasztás a sugárban lévő abrazív por, víz és levegő keveréke hatására jön létre. Vízsugaras vágásnál nagyon kicsi a vágóerő, ami lehetővé teszi hosszú és viszonylag kis átmérőjü alkatrészek vágását. Az eljárás alkalmas rideg és nehezen vágható anyagok, mint például üveg, kerámia, kompozitok, illetve különböző szuper- vagy titánötvözetek vágására [1].

\section{A bevágási mélység vizsgálata a vágás hatékonyságára}

Vízsugaras esztergáláskor a leválasztott anyag vastagsága számtalan paramétertő függ és nehezen becsülhető. Elözetes technológiai kísérletek nem álltak rendelkezésre, ezért a korábban felhalmozott úgynevezett bevágási kísérletek eredményeit használtam fel a vízsugaras esztergálás során leválasztható anyagréteg vastagságának meghatározására. A vízsugaras vágógépen végzett esztergálás során a vágási mélységet az adott paraméterekkel elérhető bevágási mélység határozza meg, mely a hatóidőtől $\left(t_{\text {eff }}\right)$, a nyomástól $(\mathrm{p})$, valamint az abrazív tömegáramtól $\left(\mathrm{m}_{\mathrm{a}}\right)$ függ. Vízsugaras vágáskor a bevágási mélység nagyságának egyik alapvető meghatározója a sugár és a munkadarab kölcsönhatásának ideje ( $\left.\mathrm{t}_{\mathrm{eff}}\right)$. Ez az idő a sugár átmérőjéből és haladási sebességéből határozható meg, ami lehetővé teszi, hogy normál bevágási kísérletek eredményeit használjuk fel a vízsugaras esztergálás során leválasztott anyagvastagság meghatározására.

A vágási kísérletek alapján a bevágási mélység különböző matematikai modellekkel meghatározható. A bevágási mélység meghatározására az egyik leggyakrabban alkalmazott matematikai modell Monno [3] modellje:

$$
k=A \frac{p^{B} \cdot m_{L}^{C}}{v_{f}^{D}}
$$

ahol k: bevágási mélység [mm], p: nyomás [MPa], $\mathrm{m}_{\mathrm{a}}$ : abrazív tömegáram [g/min], $\mathrm{v}_{\mathrm{f}}$ : előtoló sebesség [mm/min], A, B, C, D konstansok.

Ezen technológiai paraméterek hatását szemlélteti a 2. ábra alumíniumötvözet anyag vágása esetén.

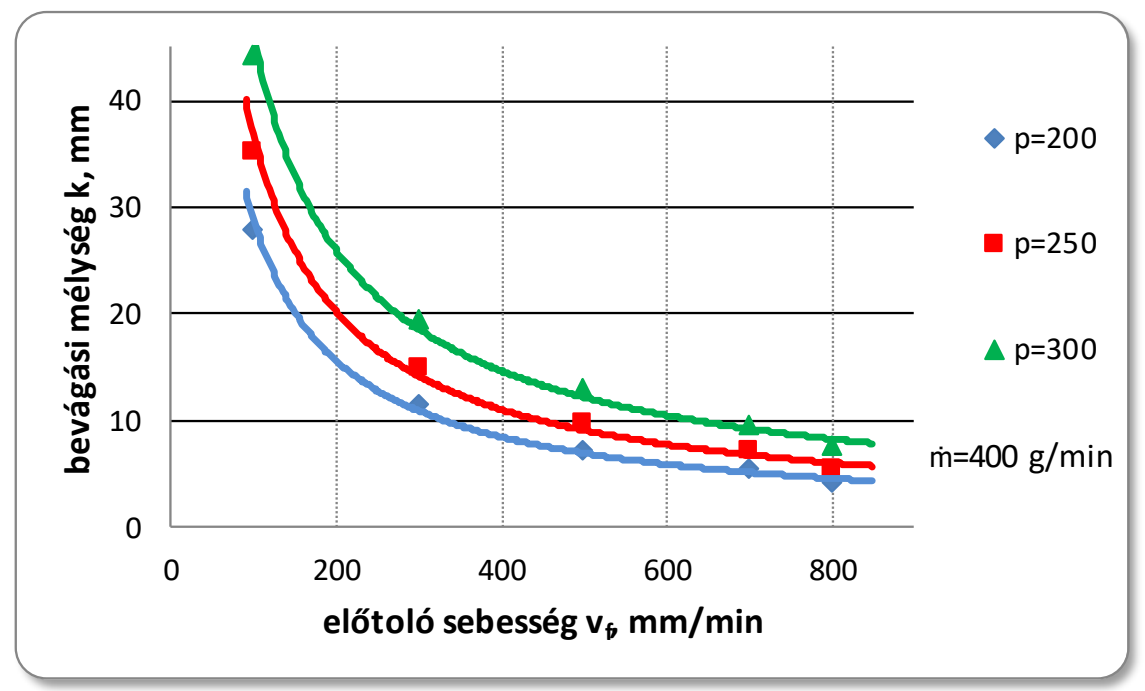

2. ábra: Az előtolás hatása a bevágási mélységre (k) különböző nyomásokon és abrazív áram esetén aluminium ötvözet vágásakor 
Az (1) egyenlet vagy a vágási kísérleten alapuló diagramok (2. ábra) segítségével a bevágási mélység becsülhető. Egy adott vágásnál a sugárnak a munkadarab egy adott pontjára gyakorolt hatóideje kiszámítható a sugár átméröjének és az előtolásnak a hányadosából.

$$
t_{\text {eff }}=\frac{d j}{v f}
$$

ahol teff: a hatóidő [min], $\mathrm{d}_{\mathrm{j}}$ : a sugár átméröje [mm], $\mathrm{v}_{\mathrm{f}}$ : az előtolás sebessége [mm/min].

Ha a hatóidők egyenlőek a különböző vágásoknál, akkor a bevágás mélységét csak a nyomás (p) és az abrazív tömegáram $\left(\mathrm{m}_{\mathrm{a}}\right)$ határozza meg. Amennyiben a vízsugaras esztergálásnál is meg tudjuk határozni a behatás idejét, úgy a bevágási kísérletek eredményei alapján megadható az esztergálással leválasztott tényleges anyagvastagság. [1,2]

\section{Esztergálás abrazív vízsugárral}

A vízsugaras vágást általában kétdimenziós mozgást lehetővé tévő szerszámgépeken végzik. Ahhoz azonban, hogy vízsugaras vágógépen lehessen forgástestet megmunkálni, szükségünk volt egy forgatóberendezésre, mely lehetővé teszi egy ilyen berendezésen a megmunkálás kiterjesztését egy eszterga-szerủ megmunkáló rendszerben. Ezért a vízsugaras vágógéppel végezhető esztergálási kísérletekhez olyan berendezést terveztünk és gyártottunk, mely teljesiti az alábbi követelményeket:

- a gép munkaterébe stabilan beépíthető,

- biztosítja az előgyártmány befogását és forgómozgását,

- lehetővé teszi a víz alatti megmunkálást a hajtómü vízvédő tartálya, valamint egy vízvédő búra segítségével,

- állítható a fordulatszám [4].

A tervezés során a munkadarab forgató berendezést három föbb egységre osztottuk: egy hajtómüre, egy vízvédő szerkezetre és egy tartószerkezetre. Mivel annak vizsgálatát is tervezzük, hogy hogyan befolyásolja a vágott felület minőségét a forgás iránya, ezért irányváltóval terveztük a hajtóművet.

Az alkatrészek tervezése, majd legyártása után összeszerelésre került a 3. ábrán látható forgató berendezés.
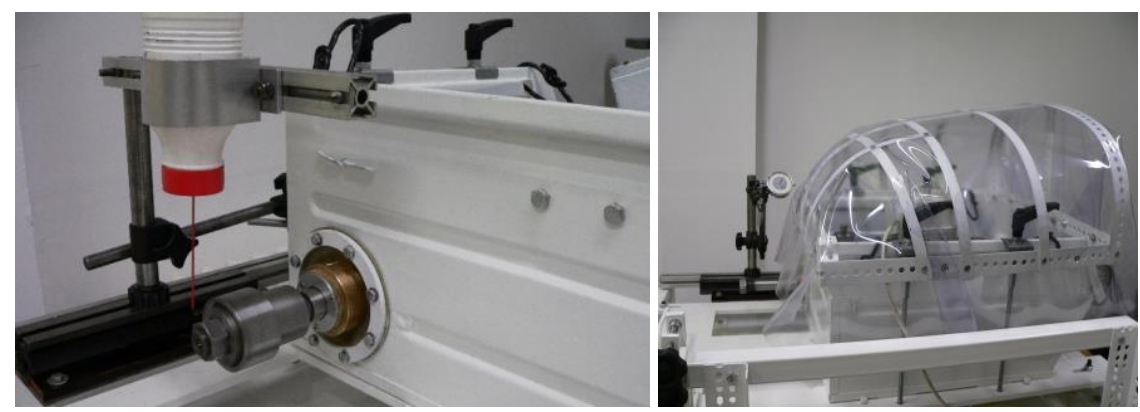

3. ábra: Forgató berendezés vizsugaras esztergáláshoz

A fentiekben bemutatott forgástest megmunkáló egység csatlakozó méretei egy CORTINA DS2600 típusú vízsugaras vágógéphez lettek kialakítva. A forgató berendezés ezen a gépen, mint alapgépen, lehetővé teszi esztergálási kísérletek végrehajtását, ehhez azonban ismernünk kell az adott paraméterek és beállítások mellett leválasztott réteg vastagságát. 


\subsection{A forgató berendezés adaptálása, kísérleti körülmények}

A vízsugaras vágógépen történő esztergálási kísérletek elvégzésére a miskolci telephelyű DINAS Kft.nél került sor, ahol a vízsugaras vágógép használatán túl rengeteg segítséget kaptam a forgató berendezés telepítése és az előkísérletek tervezése során. Az elsődleges feladat az volt, hogy a forgató berendezést stabilan a vízsugaras vágógép munkaterébe építsük, amin időközben történtek változtatások, ezért a beépítés során apróbb módosításokra volt szükség. Eredetileg a berendezés tartályát a vízsugaras vágógép munkaterébe süllyesztettük volna, hogy csökkentsük a zajszintet és a visszacsapódó vizet, de az időközben adódó problémák miatt végül a tartólemezre helyezve a tartályt leengedtük a vízszintet úgy, hogy a berendezés a vízszint fölé kerüljön.

Az előkísérleteket szerkezeti acél és $\mathrm{AlMg} 0,7 \mathrm{Si}$ ötvözet próbatesteken végeztem, melyhez a korábbi, azonos anyagokon végzett bevágási kísérletek alapján állítottam össze a kísérletek során alkalmazható lehetséges technológiai adatokat. A kísérletek során állandó és változtatott paraméterekkel dolgoztunk. Elsősorban a vágófej előtoló sebességének $\left(\mathrm{v}_{\mathrm{f}}\right)$ és a munkadarab fordulatszámának (n) hatását kívántuk vizsgálni, a további jellegzetes technológiai paramétereket, mint a víznyomás (p) és az abrazív tömegáram nagysága $\left(\mathrm{m}_{\mathrm{a}}\right)$, állandó értéken tartottuk, azaz 3000 bar nyomást és $400 \mathrm{~g} / \mathrm{min}$ körüli abrazív tömegáramot állítottunk be. Az előtolást $5-15 \mathrm{~mm} / \mathrm{min}$ között, valamint a motor fordulatszámát 100 - 2000 ford/min között változtattam. A kísérleteket egy-egy próbatesten tangenciális és radiális esztergálás (1. ábra) esetére végeztem ugyanazon technológiai paraméterek mellett.

A tapasztalatok alapján a kiértékeléseket már csak az AlMgSi ötvözet próbatestekre korlátoztam, mert az acél próbatestek nagyon hamar, már a kísérletek végzése közben elkezdtek korrodálni, így a tervezett sztereómikroszkópos vizsgálatok, fotók nem adtak számunkra használható eredményt. A felületi érdességet profil és térbeli érdességi paraméterekkel szerettük volna jellemezni, melyhez a méréseket egy AltiSurf 520 típusú érdességmérő berendezésen végeztem, valamint ZEISS Stereo Discovery.V8 mikroszkóppal készített makro- és mikro fotók segítségével vizsgáltam.

\subsubsection{Kísérleti beállítások}

A forgácsolási kísérletek elvégzése során a víznyomást állandó értéken tartottuk, változtattuk az előtoló sebesség és a munkadarab fordulatszámának nagyságát, melyhez néhány beállítási adatot az 1. táblázat szemléltet.

1. táblázat. Néhány kísérleti beállitás és paraméterei

\begin{tabular}{|c|c|c|c|c|c|c|}
\hline \multicolumn{7}{|c|}{ AlMg0,7Si } \\
\hline \multirow{2}{*}{$\begin{array}{l}\text { Próbatest } \\
\text { sorszáma }\end{array}$} & \multirow{2}{*}{ sugár } & \multirow{2}{*}{ Kísérlet } & abrazív tömegáram & nyomás & motor fordulat & elötolás \\
\hline & & & $\mathrm{g} / \mathrm{min}$ & bar & ford/min & $\mathrm{mm} / \mathrm{min}$ \\
\hline \multirow{2}{*}{1.} & 1. (érintő irányú) & 1. & 400 & 3000 & 200 & 10 \\
\hline & 2. (sugár irányú) & 2. & 400 & 3000 & 200 & 10 \\
\hline \multirow{2}{*}{2.} & 1. (érintő irányú) & 3. & 400 & 3000 & 200 & 5 \\
\hline & 2. (sugár irányú) & 4. & 400 & 3000 & 200 & 5 \\
\hline \multirow{2}{*}{3.} & 1. (érintő irányú) & 5. & 400 & 3000 & 200 & 2 \\
\hline & 2. (sugár irányú) & 6. & 400 & 3000 & 200 & 2 \\
\hline
\end{tabular}

Ugyanazon technológiai paraméterekkel, egy próbadarabon végeztünk vízsugaras esztergálási kísérleteket a radiális és tangenciális beállítás mellett (4. ábra), így az egy próbadarabon elhelyezett felületek révén vizuálisan is jól összehasonlíthatóvá vált a kétféle esztergálási módszer. 


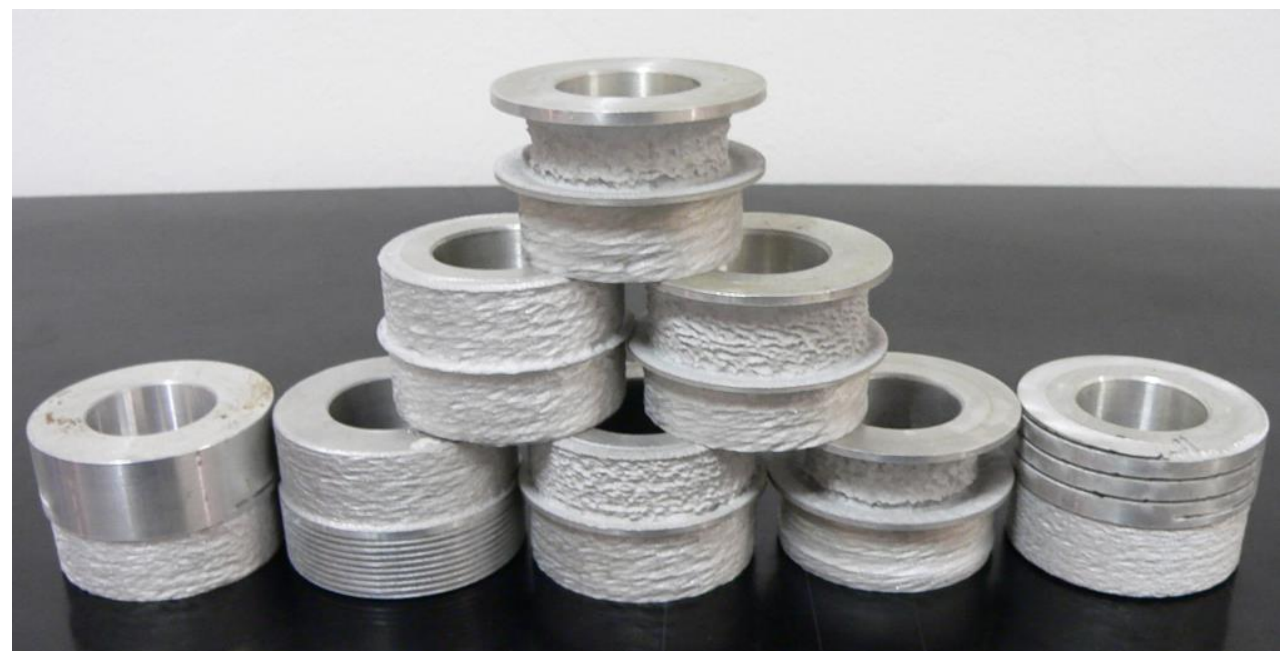

4. ábra: Radiális és tangenciális vízsugaras esztergálással megmunkált felületek

\subsubsection{Kísérleti eredmények}

A forgácsolásokat követően meghatároztuk a leválasztott anyagréteg vastagságát (5.ábra), és a felületi érdességi paraméterek közül az átlagos felületi érdesség $\left(\mathrm{R}_{\mathrm{a}}\right)$ változását.

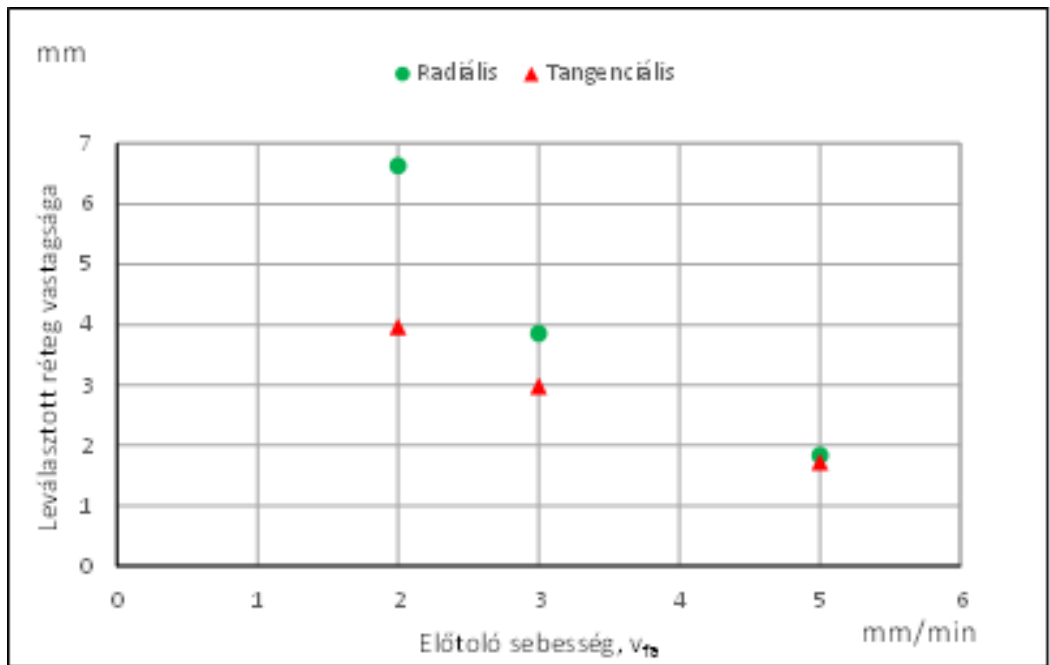

5. ábra Leválasztott anyagréteg vastagsága radiális és tangenciális vízsugaras esztergálásnál az elötolás függvényében (motorfordulat 300 1/min, abraziv áram $400 \mathrm{~g} / \mathrm{min}$ )

Az 5. ábrából megállapítható, hogy a radiális esztergálással valamennyi esetben vastagabb anyagréteg távolítható el ugyanolyan technológiai paraméterek esetén, vagyis anyagleválasztás szempontjából hatékonyabb, míg a felületi érdesség változása alapján megállapítható, hogy kedvezőbb érdességü megmunkált felületek a tangenciális vízsugaras esztergálással nyerhetők. Az érdesség változása az előtolás függvényében nem egyértelmü. [5] 


\section{4. Összefoglalás}

Az eredményeket összegezve, a kétféle vízsugaras esztergálás összehasonlítására irányuló kísérletek alapján az alábbi megállapítások tehetők:

- Azonos technológiai paraméterekkel végzett megmunkálásokkor a radiális eljárással nagyobb leválasztási hatékonyság érhető el.

- A leválasztott anyagréteg vastagsága az elötolás növelésével egyértelműen csökken.

- A felület átlagos érdessége a tangenciális eljárás esetén kisebb, az előtolás függvényében nem egyértelmű változást mutat.

- A tangenciális eljárás esetén a beállított fogásmélység nem azonos a ténylegesen leválasztott réteg vastagságával.

Összességében elmondható, hogy abrazív vízsugaras esztergálással az anyagok jól megmunkálhatók, az előírt méret betartása azonban nem kellő pontosságú. Tangenciális abrazív vízsugaras esztergálással kedvezőbb felületminőség, radiális eljárással nagyobb anyagleválasztási hatékonyság érhető el. A lejátszódó folyamatok tisztázásához további vizsgálatok szükségesek, amihez a kísérleteket márvány, gránit, mészkő anyagokon szeretném végezni.

\section{Köszönetnyilvánítás}

A cikkben ismertetett kutató munka az EFOP-3.6.1-16-2016-00011 jelü „Fiatalodó és Megújuló Egyetem - Innovatív Tudásváros - a Miskolci Egyetem intelligens szakosodást szolgáló intézményi fejlesztése" projekt részeként - a Széchenyi 2020 keretében - az Európai Unió támogatásával, az Európai Szociális Alap társfinanszírozásával valósul meg.

\section{Irodalom}

[1] Kun-Bodnár, K., Maros, Zs. A vízsugaras esztergálás kinematikai és anyagleválasztási sajátosságai. Gépgyártás 2019, 58(1-2): 53-56.

[2] Kun-Bodnár, K., Maros, Zs. Theoretical determination of removed layer depth at abrasive waterjet turning. Kharkiv 2019, ISSN 2078-7405 https://doi.org/10.20998/2078-7405.2019.90.03

[3] Brandt, S., Maros, Zs., Monno, M. AWJ Parameters Selection - a Technical and Economical Evaluation. 15th International Conference on Jetting Technology 2000, Ronneby, Sweden, pp.353-366.

[4] Kun-Bodnár, K., Kundrák, J., Maros, Zs. Machining of Rotationally Symmetric Parts with Abrasive Waterjet Cutting. IOP Conference Series: Materials Science and Engineering 2018, 448: 012053. https://doi.org/10.1088/1757-899X/448/1/012053

[5] Kun-Bodnár, K., Maros, Zs. Tangenciális és radiális vízsugaras esztergálással megmunkált felületek érdessége alumínium ötvözeten. Multidiszciplináris Tudományok 2020, 10(4): 13-19. https://doi.org/10.35925/j.multi.2020.4.2 